archives

of thermodynamics

Vol. 32(2011), No. 3, 33-43

DOI: $10.2478 /$ v10173-011-0011-7

\title{
SOFC-based micro-CHP system as an example of efficient power generation unit
}

\section{JAKUB KUPECKI* KRZYSZTOF BADYDA}

Warsaw University of Technology, Institute of Heat Engineering, ul. Nowowiejska 21/25, 00-665 Warszawa, Poland

\begin{abstract}
Microscale combined heat and power (CHP) unit based on solid oxide fuel cells (SOFC) for distributed generation was analyzed. Operation principle is provided, and the technology development in recent years is briefly discussed. System baseline for numerical analysis under steadystate operation is given. Grid-connected unit, fuelled by biogas corresponds to potential market demand in Europe, therefore has been selected for analysis. Fuel processing method for particular application is described. Results of modeling performed in ASPEN Plus engineering software with certain assumptions are presented and discussed. Due to high system electrical efficiency exceeding $40 \%$, and overall efficiency over $80 \%$, technology is an example of highly competitive and sustainable energy generation unit.
\end{abstract}

Keywords: SOFC; Modeling; Power system

\section{Introduction}

Currently, global trends in power generation point into direction of diversifying the energy portfolio. Among available technologies, dispersed energy systems are of a high attention. Number of conducted analysis point out that small scale combined heat and power (CHP) units are promising technology to satisfy local demands for heat and electricity. Various work proofed that units based on high temperature fuel cells fuelled by biogas can

*Corresponding author. E-mail address: jakub.kupecki@itc.pw.edu.pl 
achieve substantially higher efficiency, comparing to conventional systems based on the same fuel [1]. Electrical efficiency of current state-of-the-art CHP system employing solid oxide fuel cell (SOFC) can be as high as 45$48 \%$, with overall efficiency exceeding $80 \%$. In comparison, currently used systems based on micro turbines, internal combustion engines, and other technologies correspond to overall efficiency in range of $15-35 \%$ [2].

This paper provides a brief summary of various small-scale CHP systems based on SOFC and presents typical scheme of calculations for such system. Numerical approach to analysis of discussed systems using ASPEN Plus modeling environment is given. That tool prooved to be suitable for analysis of fuel cell-based systems of wide range of configurations and power output by various researchers [3-6]. Authors discuss the results of performed analysis and provide the final summary.

Microscale power unit with an output of $0.7-1.5(2.0) \mathrm{kW}_{e l}$ was considered as an interesting, highly efficient alternative to currently used, commercially available solutions for detached dwellings. Technology becomes competitive even taking into account high current price. The two main units, already in a demonstration stage of development should be mentioned:

- HEXIS Galileo 1000N SOFC $1 \mathrm{~kW}_{\text {el }} / 2 \mathrm{~kW}_{t h} \eta_{e l}>30 \% \quad \eta_{\text {overall }}>90 \%$

- Vaillant SOFC $1 \mathrm{~kW}_{\text {el }} / 1.7 \mathrm{~kW}_{t h} \quad \eta_{e l}=32 \% \eta_{\text {overall }}=85-90 \%$

Other products, already penetrating the market, include those developed by Kyocera, JX Nippon, TOTO, Gastar/Rinnai, Toyota/Aisin.

Development of SOFC-based micro cogeneration units started at a price of prototype of approximately $15000 \mathrm{EUR} / \mathrm{kW}_{e l}$, further development should allow demonstration at a price of $5000 \mathrm{EUR} / \mathrm{kW}_{e l}$. The same value should be acceptable for subsidized markets [7]. Price of commercially available CHP units should be around 3000 EUR and 2000 EUR, for small-scale and large-scale system, respectively. With proper financing mechanisms, market penetration by more expensive product is doable once the end-user price would be virtually comparable with regular CHP systems of other types. German example can be considered as a best proof of the product introduction to the local market with competitive price.

High cost of a SOFC-based CHP unit at the current stage of development is mainly due to the high fuel cell stack price, which usually makes $40-45 \%$ of the investment, additionally balance of plant $(\mathrm{BoP})$ components would make 30-40\%, control, insulation, and additional components would correspond to the rest. 
Obviously, mass production of the discussed power system will allow substantial lowering of the unit price. Number of skeptics claim that this technology will never enter the market, however the proof of the concept stage has already been achieved couple of years ago, and in several markets technology is now being commercialized. For example Japanese JX Nippon is supposed to deliver micro-CHP units based on SOFC into the local market starting in fall 2011. Product offered by the consortia, with electrical power output of $0.7 \mathrm{~kW}_{e l}$, and system target efficiency of $45 \%$ is an answer to potential demand of 1.5 million users per year in the next decade [8]. As a second example, earlier mentioned European product Galileo $1000 \mathrm{~N}$ unit by Hexis, is now at a demonstration stage of development, and should present target efficiency of over $35 \%$.

Economical competitiveness of SOFC-based micro-CHP system is a matter of fact, and comes from the high system performance, long-life operation and very small operation and maintenance costs. Large scale production of systems tailored to locally available fuel resources, ranging from natural gas, diesel fuel, methane, and biogas with proper fuel processing system will address power requirements through the dispersed generation, is possible and should be expected within the coming decade. This paper is dedicated to development of numerical tool that would allow evaluation of the product in the early stage of design and development.

\section{System baseline and fundamentals of operation}

In general, micro-CHP system based on solid oxide fuel cell would include the following components:

- SOFC stack

- Fuel processing unit ${ }^{1}$ (selection upon fuel fed)

- Afterburner

- Air blower

- Water pump and water tank

- Control unit with equipment

- Fuel preparation (clean-up) system

\footnotetext{
${ }^{1}$ Depending of a fuel used, system can be equiped with desulfurization unit, odorant removal, and other clean-up components if required.
} 
Preliminary analysis was focused on efficiency estimation and thermal balancing of a system. Components separation into two temperature zones was done mainly in order to enhance thermal integration of SOFC stack with afterburner and reformer. Separation in distinct low-temperature zone was done to protect components from breakage due to high operating temperature. Those located there include control equipment, desulfurization unit, compressor and others. This can be seen in Fig. 1.

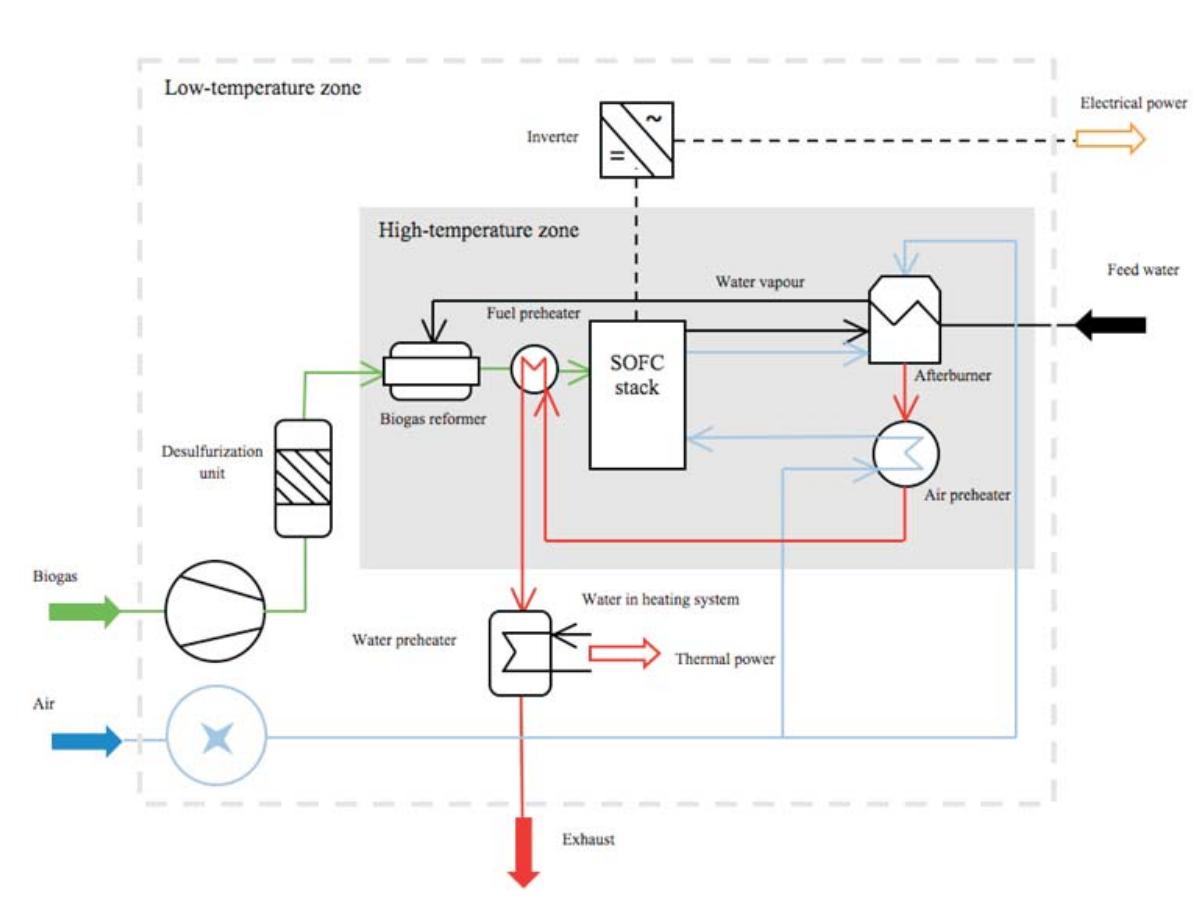

Figure 1. Preliminary outline of the micro-CHP system.

Since, steady state was analyzed in frame of presented work, only this mode of operation will be discussed. At the design point operation fuel and air are continuously delivered to the system. In the paper biogas fed system has been considered. As can be seen, fuel is delivered to the CHP unit, and in the first step desulfurization takes place. As reported by Shiratori et al. [9] sulfur content of about $1 \mathrm{ppm} \mathrm{H}_{2} \mathrm{~S}$ would lead to poisoning of the catalyst, reaction rate reduction of $40 \%$, and voltage drop of $9 \%$, hence it must be avoided. Value of $0.5 \mathrm{ppm}$ of $\mathrm{H}_{2} \mathrm{~S}$ was assumed to be acceptable, and gas should be cleaned down to this level. Next, fuel undergoes catalystbased steam reforming in order to obtain desired fuel composition. For this 
reaction constant water flow is to be maintained.

Operation of the stack with fuel utilization of $0.7-0.8$ allows combustion of depleted fuel in afterburner unit [10]. Reaction taking place in a steam reformer unit requires delivery of heat from external source. Thermal integration of reformer with afterburner allows overcoming this issue.

Additionally, slight amount of heat generated within the SOFC stack can support endothermic reforming reaction. Remaining post-combustion heat can be extracted from exhaust gases by a number of heat exchangers, presented in Fig. 1. In the first stage, exchange at high temperature between flue gases and air takes place. Secondly, fuel is preheated to about $650-750{ }^{\circ} \mathrm{C}$, and eventually before exhaust gases are vented to the atmosphere, hot water is produced either for heating purposes or for direct use. System is equipped with a number of auxiliary components, including automation and control, power conditioning, valves and flow meters. Complexity of a CHP-unit is expected to be as low as possible to allow cost reduction.

If a system is designed to meet heating requirements, then continuous heat extraction from the unit takes place. In case when hot water production is a goal, storage tank would be crucial for compensation of daily or weekly demand variations. Authors estimated that selection of stateof-the-art tank with volume of $600 \mathrm{l}$ would allow storage of $28 \mathrm{kWh}$ at the temperature of $50{ }^{\circ} \mathrm{C}$. Such capacity is believed to be sufficient for detached dwelling, and can be easily incorporated into the system. Supplementary small circulation pump placed before the water preheater on exhaust pipeline would allow efficient charging of a tank.

Initially performed calculations indicated that high fraction of power is consumed by auxiliary equipment. Further development of system design was focused on the reduction of parasitic losses. In case of employed steam reforming of biogas, there is a particular requirement for water delivery in order to sustain reforming reaction. In the initial design of the system, constant deionized water supply was considered. Due to the fact that there is a high power requirement for water evaporation, ca. $400 \mathrm{~W}_{e l}$ if electrical heater or additional heat exchanger can be utilized, however that would lead to overall system performance drop. To reduce power requirement for water deionization and demineralization, recirculation of the anode gases was proposed [11]. According to the SOFC operation principle, there is constant water generation within the stack, and this water can be simply used for steam reforming process. It can be calculated that recirculation of $40-50 \%$ 
of anode gases will virtually eliminate the need for external water source.

Presented approach of course applies only to steady-state operation, start-up of the system will still require water supply. Due to the fact that water amount needed for starting up the system is relatively small - about 4-6 $\mathrm{ml}$ for 1.5-2 $\mathrm{kW}$ system, one or two liter tank should be sufficient for a certain amount of system cycles. If needed, this water reserve can be simply refilled during the maintenance of the unit.

Discussed concept of anode gas recirculation can be done in different ways. Depending on particular arrangements, compressor or ejector can be used. Evaluation of various systems and fuel processing technologies was done by Kupecki et al. [12]. Generally two concepts are considered to be doable: compressor- and ejector-based recirculation. Those can be seen in Figs. 2 and 3, respectively.

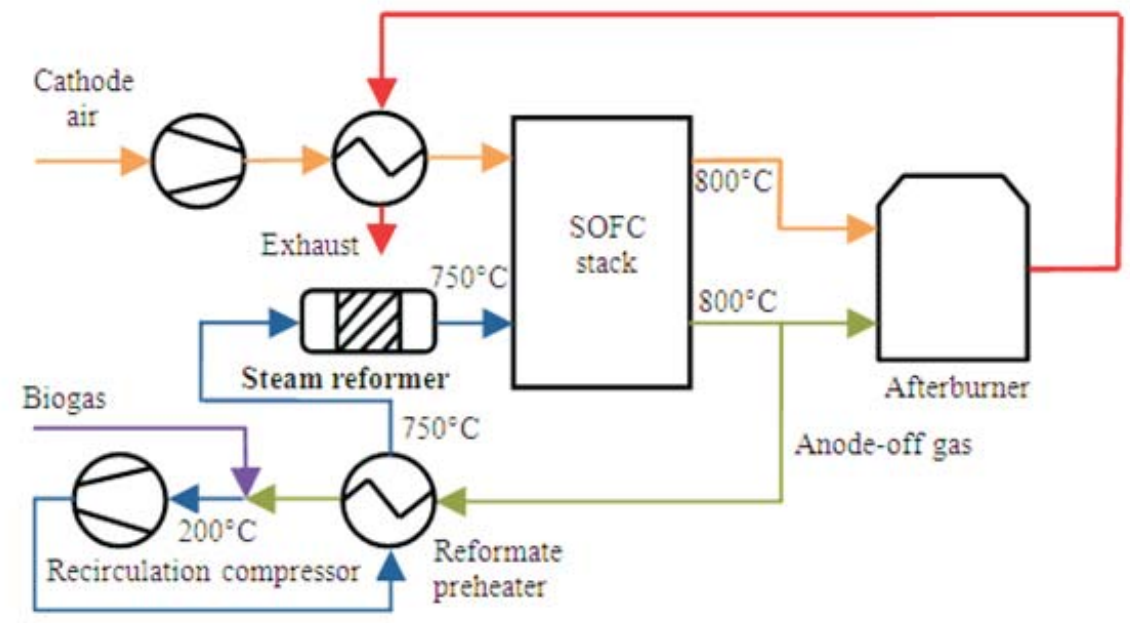

Figure 2. Micro-CHP system with anode gas recirculation based on compressor.

System based on compressor requires cooling of the recycled stream of anode gases in order to allow selection of low-temperature compressor. In configuration with ejector, much simper arrangement can be employed. Due to the fact that ejector is a robust and temperature resistant element, cooling is not required. System presented in Fig. 3 have been appreciated for durability of the ejector, however question of control and operation at partial load and transients is a big issue. Certainly, ejector requires initial pressure increase for efficient operation and will unsuitable for transient and out of design point operation without additional equipment. Despite the fact that 


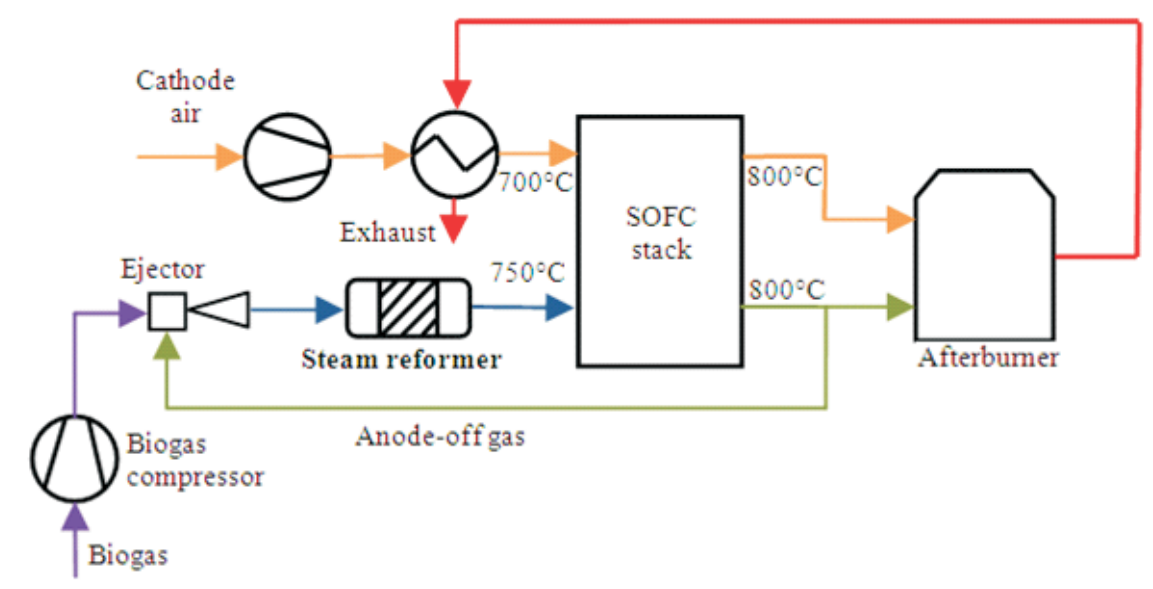

Figure 3. Micro-CHP system with anode gas recirculation based on ejector.

number of disadvantages can be listed for ejector-based recirculation, this solution is still under consideration by various groups.

In the second system, where control of the recycled anode stream is done by compressor speed adjustment, is presented in Fig. 2. Due to precise control and ability to operate in any possible mode, compressor-based recirculation is a better selection o considered application.

\section{Analysis}

In scope of current analysis, the grid-connected system, fueled by locally generated biogas was considered. According to the system configuration is presented in Fig. 2 model of the system was created in ASPEN Plus modeling and optimization environment. All data for components included were based on technical specification of the off-the-shelf components. The SOFC stack performance, based on commercially available stack was implemented in the software as FORTRAN subroutine. Ceramic anode-based fuel cell was selected, and approximate current-voltage functions were generated based on experiments. Created model took into account looses associated with limited performance of system components, thermal looses from the hot box where the fuel cell stack, reformer, and afterburner where located. Looses from the system to environment, which were estimated on assumption of outer temperature of a $\mathrm{CHP}$ unit casing not exceed $50{ }^{\circ} \mathrm{C}$ were taken into account. Auxiliary power of water pump, air compressor, control and 
automation equipment, were basically subtracted from the electrical power output of the SOFC stack.

Through performed experiments, optimal fuel cells operating point was determined. With the fuel utilization ratio of 0.7 , it was possible to burn depleted fuel in the afterburner unit. Integration of afterburner, SOFC stack, and reformer in hotbox allowed thermal balancing. Heat loss from the system was estimated to approximately $250 \mathrm{~W}$, and that number was subtracted from thermal power of the unit.

Heat exchange between flue gas, air, and fuel was modeled by available ASPEN Plus blocks. Their performance was based on the pitch temperature assumption. Approximate function was used for power output calculation, and allowed determination of the final value at any current density considered. Formula (1) available in literature [13] was implemented in the model for cell voltage approximation. Coefficients were estimated by fitting Eq. (1) to experimental data for particular fuel cell analyzed

$$
V=O C V-D \times \ln \left(\frac{i}{b}\right)-i \times A_{R} \times \exp \left(\frac{\Delta E}{R T}\right)
$$

and

$$
A_{R}=A\left(x H_{2} L O C A L\right)^{a}
$$

where:

$O C V \quad-$ open circuit voltage, $\mathrm{V}$,

$\Delta E \quad-$ activation energy, $\mathrm{J} /$ mole,

$R=8.314 \quad-$ gas constant, $\mathrm{J} / \mathrm{mol} / \mathrm{K}$,

$T \quad-$ cell operating temperature, $\mathrm{K}$

$i \quad-$ cell current, A

$x \mathrm{H}_{2} \mathrm{LOCAL}-\mathrm{l}$ local concentration of hydrogen,

$a, A, b, B, D \quad-$ coefficients determined by fitting procedure.

As can be seen in Fig. 4, computed values were in good agreement with experimental data, especially in the moderate current density range. Applied experimental data were provided by the Fuel Cell Department of the Institute of Power Engineering in Warsaw, Poland.

\section{Results}

Created model took into account all major looses that would normally occur in the operating unit. Determination of cell voltage was done using 


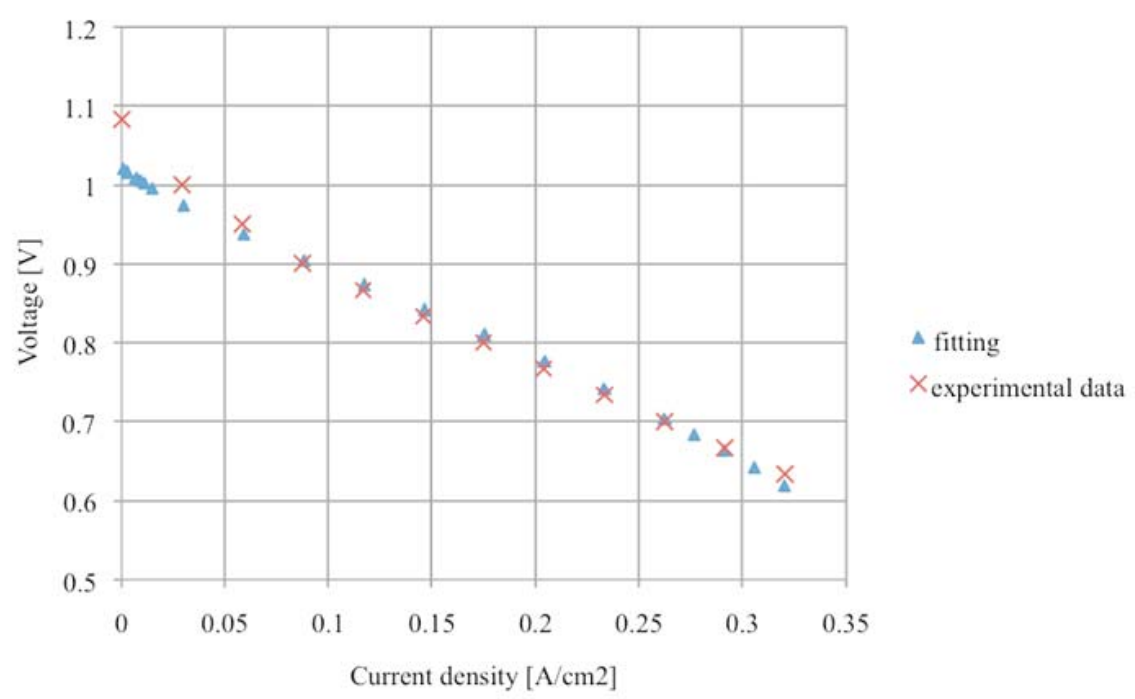

Figure 4. Fitting of approximate voltage formula to collected experimental data.

approximate function, based on experimental data for $5 \times 5 \mathrm{~cm}$ ceramic solid oxide fuel cell. Overall performance of the preliminary unit configuration, confirmed expected high electrical efficiency of $38.78 \%$, and overall efficiency $67.79 \%$. Selection of the recirculation-based system eliminated energetically intensive water preparation and evaporation. This led to electrical efficiency increase by additional 7-9 percent points, depending on recirculation ratio and other operational parameters. Achieved gross power output was $2168 \mathrm{~W}_{e l}$, and $1237 \mathrm{~W}_{t h}$, therefore thermal to power ration (TER) of analyzed unit was 0.57. Since biogas was considered as a supplied fuel the desulfurization was required. Two-stage process was considered to allow driving $\mathrm{H}_{2} \mathrm{~S}$ content down to $0.5 \mathrm{ppm}$ in the gas directed to the steam reformer.

Results obtained in through modeling, point out that future work should be mainly focused on development of the stack, advances in thermal integration of the unit and reduction of parasitic looses. Authors believe that the last can be achieved by selection of tailored auxiliary equipment. Among various issues the long life of desulfurization unit is expected, and in the simplest case that can be done by over sizing the sorbent cartridge volume, but on the other hand that would lead to a significant pressure drop increase. Determination of the optimal size would be a matter of future work. Enhanced isolation of high temperature zone by implementation of 
advanced insulation materials can play a major role.

\section{Conclusions}

Theoretical performance of discussed system has been evaluated in a designpoint operation. Obtained efficiency corresponds to available literature covering the topic $[14,15]$. Solid oxide fuel cell based dispersed heat and power generation is already technically achievable. Mass scale production of those systems will allow substantial price reduction. Technology should have commercial potential for subsidized market at a unit price of $4000 \mathrm{USD} / \mathrm{kW}$ of power installed. At such price level system is expected to be economically feasible and ready to penetrate the market.

It is expected that within the Europe there are more than 500000 potential users who might be interested, at least 100000 just in Germany. Taking into account high biomass availability in Poland, SOFC-based micro-CHP system should be considered as a prospective technology for distributed power and heat generation in the country. It must be emphasized that depending on local regulations, system will need to have a particular design. One of the biggest differences in the outline would come from the fact if the units were grid-connected or not. In case of Europe, the earlier micro-CHP unit would be of consideration, while in Japan micro-CHP unit is not allowed by law to be connected to the national grid, therefore the later would be commercialized. Such variations between different markets are meaningful during research and development, and cannot be neglected.

Future work should be dedicated to modeling of off-design and transient operation. Degradation analysis would be crucial for evaluation of long life operation of the system exposed to thermal cycling during start-up and shut down.

Acknowledgements Authors acknowledge Janusz Jewulski from Fuel Cell Department, of the Institute of Power Engineering in Warsaw, Poland for providing experimental data for the current analysis.

This research has been financially supported within the framework of the project „Didactic Development Programme of the Faculty of Power and Aeronautical Engineering of the Warsaw University of Technology" financed within the Operational Programme Human Resources. 


\section{References}

[1] Van Heerle J., Membrez Y., and Bucheli O.: Biogas as a fuel source for SOFC co-generators. J. Power Sources 127(2004), 300-312.

[2] Layi Fagbenle R., Oguaka A.B.C., Olakoyejo O.T.: Thermodynamic analysis of a biogas-fired intefrated gasification steam injected gas turbine (BIG/STIG) plant. Appl. Therm. Eng 27(2005), 2220-2225.

[3] Barelli L., Bidini G., Gallorini F., Ottaviano A.: An energetic-exergetic comparison between PEMFC and SOFC-based micro-CHP systems. Int. J. Hydrogen Energy 36 (2011), 3206-3214.

[4] Braun R.J.: Optimal Design and Operation of Solid Oxide Fuel Cell System for Small-scale Stationary Applications. PhD dissertation at University of WisconsinMadison, 2002.

[5] Milewski J., Miller A., Salacinski J.: Off-design analysis of SOFC hybrid system. Int. J. Hydrogen Energy 32(2007), 6, 687-698.

[6] Kupecki J.: Integrated Gasification SOFC Hybrid Power System Modeling: Novel numerical approach to modeling of advanced power systems. VDM Verlag Dr. Müller, 2010, ISBN 978-3639286144.

[7] Steinnberger-Wilckens R.: FZ Julich, personal communication, IX 2011.

[8] Toshiyki U.: JX Nippon, personal communication, IX 2011.

[9] Shiratori Y., Oshima T., Sasaki K.: Feasibility of direct-biogas SOFC. Int. J. Hydrogen Energy 33(2008), 21, 6316-6321.

[10] Fuel Cell Handbook, 7th edn. EG\&G Technical Services, Inc. Under Contract No. DE-AM26-99FT40575. U.S. Department of Energy, 2004.

[11] BedringÅs K.W., Ertesvåg I.S., Byggstøyl S., Magnussen B.F.: Exergy analysis of solid-oxide fuell-cell systems. Energy 22(1997), 4, 403-412.

[12] Kupecki J., Jewulski J., BAdyda K.: Evaluation and selection of fuel processing technology for SOFC-based micro-CHP unit in dispersed generation. In: Rynek Ciepła - Materiały i Studia, ISBN: 978-83-927680-7-4, 2011, Nałęczów, Poland (in Polish).

[13] Yoshiba F., Yamamoto T., Yoshikawa M., Mugikura M., Watanabe T.: Development of estimation method on SOFC system performance. In: Proceedings of the Second European Fuel Cell Technology and Applications Conference, XII 2007.

[14] National Renewable Energy Laboratory. 1-10 kW Stationary Combined Heat and Power Systems Status and Technical Potential. NREL/BK-6A10-48265, 2010. 